\title{
Effect of Milking Interval on Alveolar Versus Cisternal Milk Accumulation and Milk Production and Composition in Dairy Ewes
}

\author{
B. C. McKusick, ${ }^{\star}$ D. L. Thomas, ${ }^{*}$ Y. M. Berger, $\dagger$ and P. G. Marnetł \\ *Department of Animal Sciences \\ †Spooner Agricultural Research Station \\ University of Wisconsin, Madison 53706 \\ $\ddagger$ Institut National de la Recherche Agronomique, UMR production du lait \\ 35042 Rennes, France
}

\section{ABSTRACT}

Cisternal and alveolar milk fractions were measured in East Friesian crossbred dairy ewes $(\mathrm{n}=32)$ after 4 , $8,12,16,20$, or $24 \mathrm{~h}$ of milk accumulation in a $6 \times 6$ Latin square design by administration of an oxytocin receptor antagonist for recuperation of cisternal milk followed by injection of oxytocin to remove the alveolar fraction. Less than half (38 to $47 \%$ ) of the total milk yield was stored within the cistern for the first $12 \mathrm{~h}$ of udder filling compared with up to $57 \%$ after $24 \mathrm{~h}$ of udder filling. Subsequent milk yield was significantly reduced following the 16-, 20-, and 24-h treatments. Cisternal milk fat percentage, but not milk protein percentage, was lower than in alveolar milk (4.49 vs. $7.92 \%$ milk fat, respectively), indicating that casein micelles pass more freely from the alveoli to the cistern between milkings compared with fat globules. Alveolar compared to cisternal somatic cell count was higher for the 16-, 20-, and 24-h treatments. Significant increases in cisternal milk yield and milk composition observed for the 24-h compared with the 20-h treatment demonstrated the importance of the cistern as a storage space when the alveoli and small intramammary ducts became full. The main difference between cisternal and alveolar milk fractions is the poor fat content of cisternal milk, which is an important reason for the milk ejection reflex to be present during machine milking of dairy ewes. In a second experiment, milking every $16 \mathrm{~h}$ compared with every 12 $\mathrm{h}$ during mid- to late-lactation did not effect milk yield, milk composition, and quality, or lactation length; however, a $25 \%$ savings in labor was achieved with the longer milking interval.

(Key words: East Friesian, milk fraction, milk fat, milking interval)

Received November 19, 2001.

Accepted February 27, 2002.

Corresponding author: B. C. McKusick; e-mail: brett.mckusick@ orionpharma.com.

\begin{abstract}
Abbreviation key: $\mathbf{1 2 H}$ = treatment group of twice daily machine milking, $\mathbf{1 6 H}$ = treatment group of three machine milkings in $48 \mathrm{~h}$.
\end{abstract}

\section{INTRODUCTION}

Milk within the udder of dairy ruminants can be divided into two fractions: the cisternal fraction, which has already been transferred from the alveoli to the cistern during the intermilking interval and is immediately obtainable without milk ejection, and the alveolar fraction, which can be removed from the udder only if milk ejection occurs during machine milking. Large differences between dairy species exist with respect to the proportion of total milk that can be stored within the cistern. For example, following a normal milking interval of 12 to $14 \mathrm{~h}$, the dairy ewe and goat can store up to $75 \%$ of the total milk volume within the cistern (Marnet and McKusick, 2001), whereas the cisternal fraction in dairy cattle accounts for approximately $20 \%$ of total milk volume (Pfeilsticker et al., 1996).

Indeed, there are several reports that demonstrate the differences in distribution and accumulation of cisternal and alveolar milk fractions in dairy cattle and goats. Knight et al. (1994a) constructed mathematical models for the transfer of milk from the alveoli to the cistern in dairy cattle over a 20 -h period and found that secreted milk does not readily appear in the cistern until 4 to 6 $\mathrm{h}$ following udder emptying. These findings differ from one report in dairy goats (Peaker and Blatchford, 1988) and one report in dairy cows (Stelwagen et al., 1996) in which alveolar and cisternal milk accumulation is linear for the first $6 \mathrm{~h}$. Despite the interest in delineating cisternal and alveolar milk storage within ruminant udders, distribution of milk between the two sites in East Friesian ewes is poorly understood. Furthermore, techniques for determining alveolar and cisternal milk fractions have been improved and now include the use of an oxytocin receptor antagonist (Knight et al., 1994b; Wellnitz et al., 1999). Knowledge of the udder-filling pattern and distribution of milk within the udder of 
dairy ewes would be useful in determining appropriate milking intervals for this species.

Efforts to improve milking efficiency in dairy ruminants have focused on increasing the amount of milk secreted or reducing labor required to remove milk from the mammary gland (e.g., by reducing the number of daily milkings). This is especially important for small dairy ruminant operations, which typically maintain large flocks, and, as a result, labor during milking represents about 55\% of the total labor input (Marnet and McKusick, 2001). Some dairy cow farmers-for example, in New Zealand and France-practice once-daily milking in early lactation to reduce metabolic stress (Davis et al., 1999; Rémond et al., 1999) or in late lactation to accommodate or improve quality of farming life (Davis et al., 1999). However, once-daily instead of twice-daily machine milking results in significant losses in milk production from 10 to $50 \%$ in dairy cows (Davis et al., 1999) and between 20 and 60\% in dairy ewes (Labussière, 1984).

Physiologically, milking routines should reflect intramammary filling rate and cisternal capacity to store milk. Overfilling of the udder increases intramammary pressure and distention of the alveoli, which can compromise subsequent milk synthesis (Peaker, 1980; Labussière, 1993). An increase in cisternal storage capacity counteracts the loss in milk production when the interval between milkings increases in dairy cows (Knight and Dewhurst, 1994), dairy goats (Peaker and Blatchford, 1988), and dairy ewes (Labussière, 1988). Therefore, it is possible that longer milking intervals might be tolerated in dairy ewes because they might not suffer the same degree of loss in milk production or in lactation length with less frequent milking, as has been demonstrated in goats with very large cisterns in which there was no significant difference in milk production between once- or twice-daily milked Canary Island does (Capote et al., 1999). Moreover, simplification of the milking routine would likely result in significant savings in labor and expenses.

In dairy ewes, little research has been conducted on appropriate milking intervals. Researchers in France and Sardinia have tested the effect of omitting one or both of the Sunday milkings to enable farmers to spend more time with their family and other off-farm activities. They reported losses of 5 to $25 \%$ in milk production (Casu and Labussière, 1972; Labussière et al., 1974; Labussière, 1988). The effect of longer milking intervals (i.e., $24 \mathrm{~h}$ ) over a long period of time on commercial milk production and lactation length is not known. Three milkings in $48 \mathrm{~h}$ is a milking-interval system intermediate to once- or twice-daily milking systems. However, there are no reliable reports on 16-h milking intervals in dairy ewes and only one published study in dairy cows, where yield losses of 7 to $18 \%$ were reported (Woolford et al., 1985).

We hypothesize that a 16 -h milking interval would be appropriate for midlactation dairy ewes because of their large cisternal storage capacity and the fact that a 16$\mathrm{h}$ time period lends itself to organization of the milking routine to include three milkings every $48 \mathrm{~h}$ (e.g. 0600, 2200 , and $1400 \mathrm{~h}$ ). The objectives of the present experiment were to first measure cisternal and alveolar fractional milk yield and composition after 4, 8, 12, 16, 20, and $24 \mathrm{~h}$ of udder filling in order to understand how milk accumulates within the udder of East Friesian crossbred dairy ewes. Based on udder-filling data obtained in the first experiment, a second experiment was conducted to estimate the differences in milk production and lactation length for dairy ewes managed with either a 12- or 16$\mathrm{h}$ milking interval from mid- to late lactation.

\section{MATERIALS AND METHODS}

\section{Experiment 1}

Thirty-two fourth-parity East Friesian crossbred dairy ewes (50 to $75 \%$ East Friesian and 25 to 50\% Dorset, Polypay, and/or Rambouillet) in their third month of lactation with similar daily milk yields $(2.5 \pm 0.7 \mathrm{~kg} / \mathrm{ewe}$, mean $\pm \mathrm{SD}$ ) were studied in experiment 1 . Ewes had been selected from the University of Wisconsin-Madison's main flock of 350 dairy ewes at the Spooner Agricultural Research Station and synchronized for lambing. Ewes were housed in six pens in an indoor laboratory facility (photoperiod regime of 12:12 h light to dark) on the University of Wisconsin-Madison campus and fed a $16 \% \mathrm{CP}$ grain mix and alfalfa haylage. Machine milking was performed with a portable milker (Coburn Co., Inc., Whitewater, WI, and Interpuls Inc., Albinea, Italy) that was set to provide 165 pulsations per minute in a 50:50 ratio with a vacuum level of $37 \mathrm{kPa}$.

Ewes were randomly assigned to one of six pens (A to F), balanced with respect to milk production, for use in a $6 \times 6$ Latin square experimental design. At the morning milking $(0630 \mathrm{~h})$ immediately before treatment $(0 \mathrm{~h}), 2$ IU of oxytocin (Vedco, Inc., St. Joseph, MO) were injected intravenously to ensure milk ejection. One of six milking interval treatments $(4,8,12,16,20$, or $24 \mathrm{~h})$ was then randomly applied to each pen for the first milking of six 3 -d periods ( 1 to 6 ). Thus, a pen of ewes was milked at $1030,1430,1830,2230,0230$, or $0630 \mathrm{~h}$ for the six treatments, respectively. Following treatment administration, the next machine milking occurred at one of the two normal milking times (1830 or $0630 \mathrm{~h}$ ), and these normal milking times were continued twice daily for the remainder of each 3-d period. At the start of the next 3$\mathrm{d}$ period, oxytocin was administered at the 0630 milking (time 0 ), and the next series of treatments were applied. 
The experiment continued until all pens had received all the treatments $(18 \mathrm{~d})$.

Cisternal and alveolar milk fractions were determined only at the treatment-milking with the oxytocin receptor antagonist Atosiban (Ferring Research Institute Inc., San Diego, CA). Atosiban (1.0 mg/ewe) was administered intravenously to each ewe within a pen immediately before entering the parlor. As a result of oxytocin receptor antagonism, milk ejection during machine milking could not occur, and only the cisternal milk fraction was obtained. Cisternal milk volume was recorded and sampled for each ewe. Ewes were then injected intravenously with 2 IU of oxytocin to reestablish milk ejection and allow the alveolar milk fraction to be measured and sampled. Individual ewe cisternal and alveolar milk samples were analyzed for percentages of fat and protein, and for SCC with a Fossomatic analyzer by a State of Wisconsin certified laboratory. Somatic cell count was transformed to logarithms of base ten. Milk fat and protein yield were calculated by multiplying milk yield by milk fat or protein percentage. Total milk yield, milk fat yield, and milk protein yield at a treatment were calculated by adding cisternal and alveolar milk together. Total percentages of milk fat and protein at a treatment were calculated by dividing total milk fat or protein yield by total milk yield, and total SCC at a treatment was calculated by a weighted average of the cisternal and alveolar SCC. Milk yield was also measured $12 \mathrm{~h}$ before time 0 and at all subsequent twice-daily milkings following treatment within each 3-d period. Total 3-d milk yield was calculated by adding together all milk yields obtained during the 3-d period.

Analyses of variance were conducted with the general linear models procedure of SAS (1999) for a $6 \times 6$ Latin square design. Alveolar and cisternal fraction traits analyzed included milk yield, milk fat, and protein percentage, milk fat, and protein yield, and SCC. Independent variables and their interactions included in the models were: fraction (alveolar or cisternal), treatment $(4,8,12$, 16,20 , or $24 \mathrm{~h}$ ), pen (A to E), ewe within pen, 3 -d period (1 to 6), fraction $\times$ treatment, fraction $\times$ pen, fraction $\times$ 3 -d period, and residual error. Differences among fraction $\times$ treatment combinations were tested for significance with residual error. For the analyses of total treatment milk yield (alveolar + cisternal milk), 3-d milk yield, total milk fat and protein yield, total milk fat and protein percentage, and total SCC, fraction and its interactions were removed from the model, and differences among treatments were tested for significance with residual error. A separate analysis was performed for 12-h milk yield produced before and after treatment, and the model included the following independent variables and interactions: time (before treatment or after treatment), treatment, pen, ewe within pen, 3-d period, time $\times$ treatment, time $\times$ pen, time $\times 3$ - $\mathrm{d}$ period, and residual error. Differences among time $\times$ treatment combinations were tested for significance with residual error.

\section{Experiment 2}

Forty-eight third-parity East Friesian crossbred dairy ewes (50 to 75\% East Friesian and 25 to 50\% Dorset, Polypay, and/or Rambouillet) were studied in experiment 2 from $d 90$ to the end of lactation (d 180) at the Spooner Agricultural Research Station of the University of Wisconsin-Madison. Ewes with symmetrical udders, similar average daily milk production $(1.8 \pm 0.4 \mathrm{~kg} / \mathrm{ewe}$, mean $\pm \mathrm{SD})$, and stage of lactation $(88 \pm 7 \mathrm{~d}$, mean \pm SD) were chosen from the main dairy flock of 350 ewes that are normally machine milked twice daily. All ewes in the experiment had been weaned from their lambs at approximately $24 \mathrm{~h}$ postpartum. Ewes were randomly assigned to two milking frequency treatments for the remainder of lactation: twice-daily machine milking at 0600 and $1800 \mathrm{~h}(\mathbf{1 2 H}, \mathrm{n}=24)$, or three milkings in 48 $\mathrm{h}$ at 0600,2200 , and $1400 \mathrm{~h}$, respectively $(\mathbf{1 6 H}, \mathrm{n}=$ 24). Treatment groups were housed separately in two neighboring pens and fed a $16 \% \mathrm{CP}$ concentrate diet in the parlor and alfalfa hay in the pens.

Machine milking took place in a $2 \times 12$ high-line Casse system milking parlor with 12 milking units. The milking machine (Alfa Laval Agri Inc., Kansas City, MO) was set to provide 180 pulsations per minute in a 50:50 ratio with a vacuum level of $36 \mathrm{kPa}$. Individual ewe milk yield (morning, evening, and/or afternoon) was recorded and morning milk samples were collected every $15 \mathrm{~d}$ throughout the experiment. Milk composition was analyzed for percentage of fat and protein and SCC with a Fossomatic analyzer by a State of Wisconsin certified laboratory. Parlor time (the time for entry, machine milking, and parlor exit) was recorded every other day with a stopwatch during the morning milking for each treatment group of 24 ewes. Adjusted 24-h milk production was calculated on each test day by adding the 0600 and $1800 \mathrm{~h}$ production for the $12 \mathrm{H}$ ewes and by adding the 0600,2200 , and $1400 \mathrm{~h}$ production and then dividing by two for the $16 \mathrm{H}$ ewes. An estimation of total milk production, percentages of milk fat and protein, and total milk fat and protein yield for the 90-d experimental period was calculated according to Thomas et al. (2000). SCC was transformed to logarithms of base ten and averaged over the 90-d experiment. Ewes were removed from experiment 2 and dried-off when their daily milk production on a test day fell below $0.6 \mathrm{~kg} / \mathrm{d}$.

Least squares means analysis of variance was conducted with the general linear models procedure of SAS (1999). For traits measured multiple times on a ewe (morning milk yield and adjusted 24-h milk yield), the 
Table 1. Least squares means and SEM for milk yield and milk composition traits during experiment 1.

\begin{tabular}{|c|c|c|c|c|c|c|c|}
\hline \multirow[b]{2}{*}{ Trait } & & \multicolumn{6}{|c|}{ Milking interval treatment $(\mathrm{h})^{1}$} \\
\hline & & 4 & 8 & 12 & 16 & 20 & 24 \\
\hline \multicolumn{8}{|l|}{ Milk yield } \\
\hline Treatment yield, $\mathrm{kg}^{2}$ & & $0.39^{f}$ & $0.81^{\mathrm{e}}$ & $1.28^{\mathrm{d}}$ & $1.52^{\mathrm{c}}$ & $1.86^{\mathrm{b}}$ & $2.28^{\mathrm{a}}$ \\
\hline Cisternal fraction, $\%$ & SEM & $\begin{array}{r}0.04 \\
32.2^{\mathrm{d}}\end{array}$ & $37.8^{\mathrm{c}}$ & $46.9^{\mathrm{b}}$ & $52.4^{\mathrm{b}}$ & $51.0^{\mathrm{b}}$ & $57.4^{\mathrm{a}}$ \\
\hline $12 \mathrm{~h}$ before treatment, $\mathrm{kg}^{3}$ & SEM & $\begin{array}{l}1.8 \\
1.21^{\mathrm{a}}\end{array}$ & $1.24^{\mathrm{a}}$ & $1.23^{\mathrm{a}}$ & $1.28^{\mathrm{a}}$ & $1.25^{\mathrm{a}}$ & $1.26^{\mathrm{a}}$ \\
\hline $12 \mathrm{~h}$ after treatment, $\mathrm{kg}$ & SFM & $\begin{array}{l}1.19^{\mathrm{a}} \\
0.04\end{array}$ & $1.17^{\mathrm{a}}$ & $1.18^{\mathrm{a}}$ & $1.10^{\mathrm{b}}$ & $1.06^{\mathrm{b}}$ & $1.06^{b}$ \\
\hline Total 3-d yield, kg & SEM & $\begin{array}{l}7.24^{\mathrm{a}} \\
0.08\end{array}$ & $7.23^{\mathrm{a}}$ & $7.31^{\mathrm{a}}$ & $7.16^{\mathrm{a}}$ & $6.89^{\mathrm{b}}$ & $6.85^{\mathrm{b}}$ \\
\hline Milk composition ${ }^{4}$ & & & & & & & \\
\hline Milk fat, $\%$ & SEM & $\begin{array}{l}9.20^{\mathrm{a}} \\
0.13\end{array}$ & $7.07^{\mathrm{b}}$ & $6.26^{\mathrm{c}}$ & $5.78^{\mathrm{d}}$ & $5.67^{\mathrm{d}}$ & $5.72^{\mathrm{d}}$ \\
\hline Milk fat, $\mathrm{g}$ & SEM & $\begin{array}{c}36.3^{\mathrm{f}} \\
2.4\end{array}$ & $57.2^{\mathrm{e}}$ & $78.5^{\mathrm{d}}$ & $86.5^{\mathrm{c}}$ & $104.1^{\mathrm{b}}$ & $127.5^{\mathrm{a}}$ \\
\hline Milk protein, $\%$ & SEM & $\begin{array}{l}4.13^{\mathrm{d}} \\
0.03\end{array}$ & $4.31^{\mathrm{c}}$ & $4.51^{\mathrm{b}}$ & $4.58^{\mathrm{b}}$ & $4.57^{\mathrm{b}}$ & $4.65^{\mathrm{a}}$ \\
\hline Milk protein, g & SEM & $\begin{array}{c}15.2^{\mathrm{f}} \\
1.7\end{array}$ & $34.4^{\mathrm{e}}$ & $56.8^{\mathrm{d}}$ & $68.9^{\mathrm{c}}$ & $84.2^{\mathrm{b}}$ & $104.8^{\mathrm{a}}$ \\
\hline $\mathrm{SCC}, \log _{10} / \mathrm{ml}$ & SEM & $\begin{array}{l}5.29^{\mathrm{a}} \\
0.04\end{array}$ & $5.11^{\mathrm{b}}$ & $5.08^{\mathrm{b}}$ & $4.96^{\mathrm{c}}$ & $4.94^{\mathrm{c}}$ & $5.02^{\mathrm{bc}}$ \\
\hline
\end{tabular}

a,b,c,d,e,f Means within row(s) with different subscripts differ $(P<0.05)$.

${ }^{1}$ The first milking of a 3 -d period occurred at $4,8,12,16,20$, or $24 \mathrm{~h}(\mathrm{n}=32)$ respective to initial udder emptying with oxytocin at $0 \mathrm{~h}$. Subsequent milkings during the 3 -d period occurred at 0630 and 1830 .

${ }^{2}$ Milk yield recorded at each treatment, following udder emptying at $0 \mathrm{~h}$.

${ }^{3}$ Milk yield during the 12 -h interval immediately before treatment compared with milk yield during the first complete 12-h interval following treatment.

${ }^{4}$ Composition of milk samples at a treatment milking.

experimental design was a split plot on time for measurements taken every $15 \mathrm{~d}$ (Figure 4). The model included the main plot effects of: treatment $(12 \mathrm{H}$ or $16 \mathrm{H})$ and ewe within treatment, and the subplot effects of: day (d 90, $105,120,135,150,165$, and 180), treatment $\times$ day, and residual error. Differences among treatments were tested for significance with ewe within treatment, and differences among levels of the other effects were tested with residual error. All traits except morning milk yield and adjusted 24-h milk yield had one observation per ewe and were analyzed with a model that included the effects of treatment and residual error.

\section{RESULTS}

\section{Experiment 1}

Milk yield after udder emptying increased $(P<0.01)$ with increasing milking interval (Table 1). Cisternal fractional yield was different from that of the alveolar fraction $(P<0.05)$ at 4,8 , and $24 \mathrm{~h}$, with cisternal milk accounting for approximately $35 \%$ of the total milk yield at 4 and $8 \mathrm{~h}$ milking intervals, and $57 \%$ of the total yield at the 24-h interval (Table 1 and Figure 1). Alveolar milk yield increased $(P<0.05)$ with increasing milking interval through $20 \mathrm{~h}$, whereas cisternal milk yield in- creased $(P<0.05)$ through $24 \mathrm{~h}$ (Figure 1$)$. Milk yield during the first complete 12 -h interval following treatment was similar to pretreatment values for the 4-, 8-, and 12-h interval treatments, yet was reduced by an average of $15 \%(P<0.01)$ for the 16-, 20-, and 24-h interval treatments (Table 1). Total milk yield during a

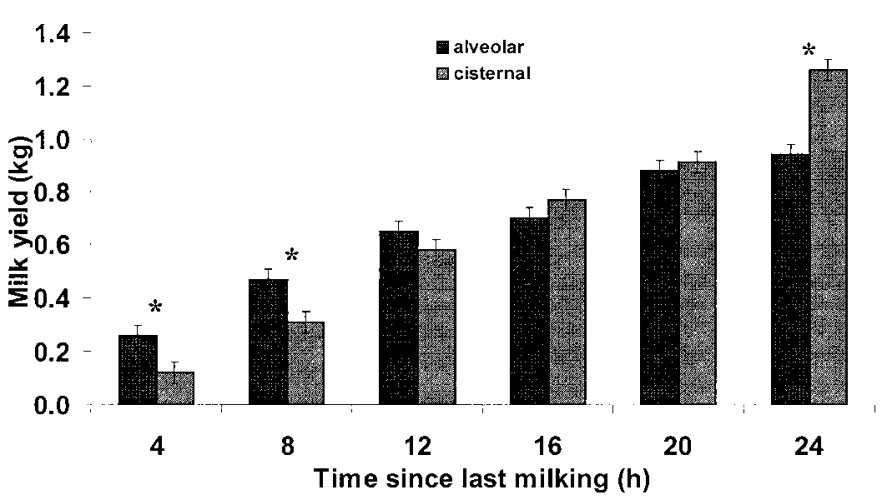

Figure 1. Alveolar and cisternal milk yield obtained 4, 8, 12, 16, 20 , and $24 \mathrm{~h}$ after the last milking. Values are least squares means \pm SEM for 32 ewes studied in experiment 1 in a $6 \times 6$ Latin square design every $3 \mathrm{~d}$ for $18 \mathrm{~d}$. Significant differences between alveolar and cisternal fractions within a time category are indicated by * $(P$ $<0.05)$. 
A

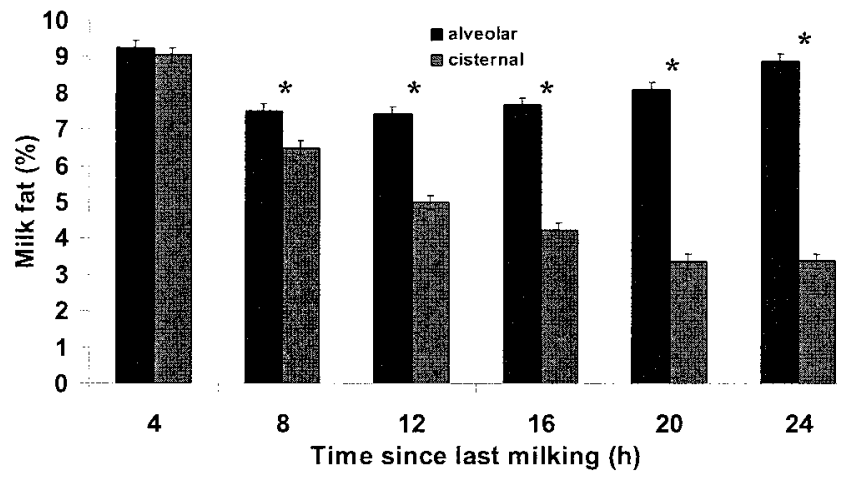

B

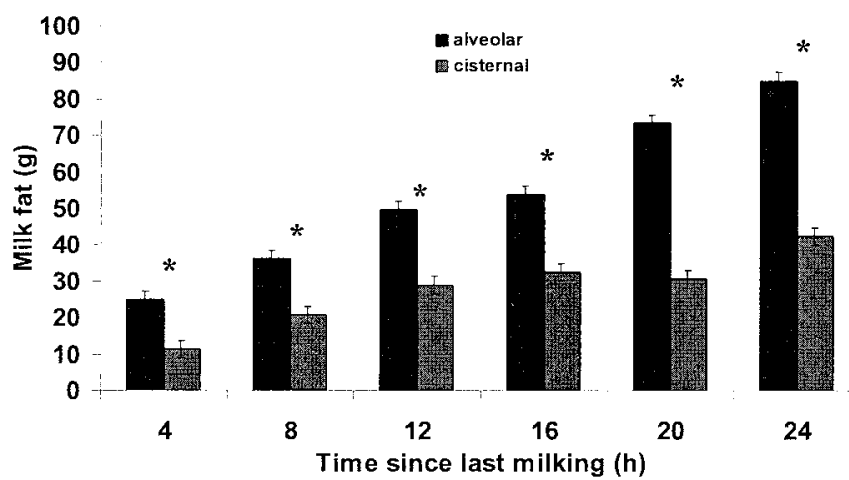

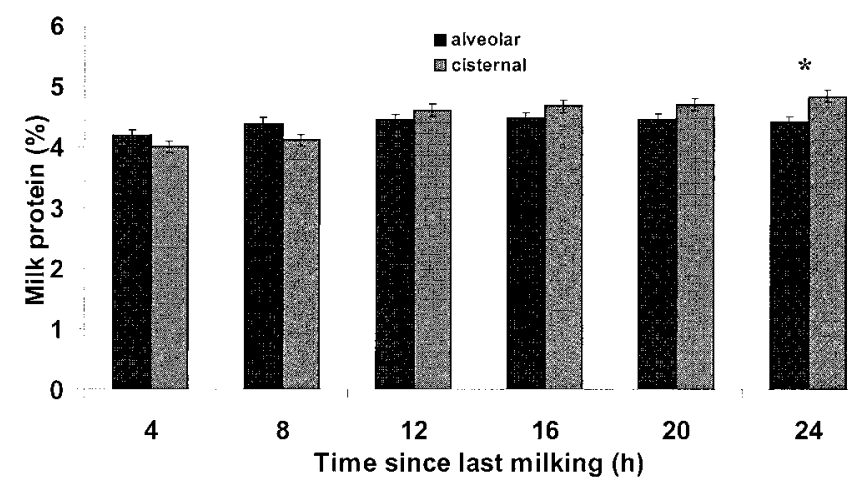

D

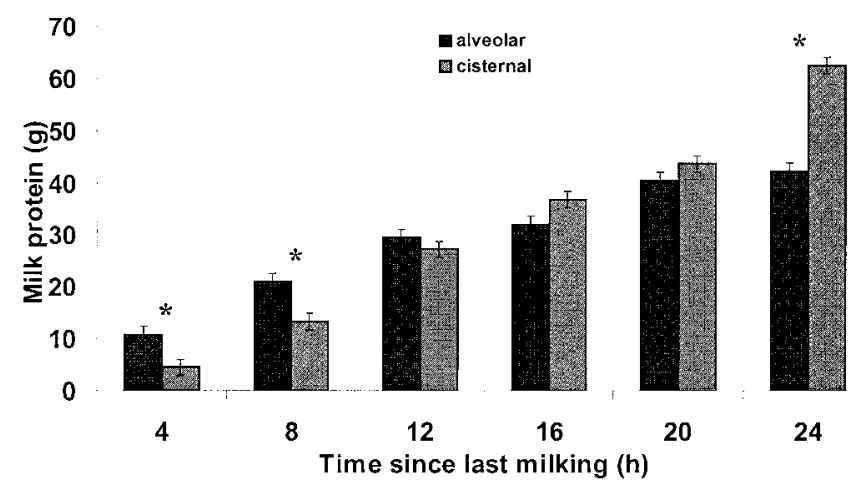

Figure 2. Milk fat percentage and yield (panels A and B, respectively) and milk protein percentage and yield (panels C and D, respectively), for alveolar and cisternal milk obtained 4, 8, 12,16, 20, and $24 \mathrm{~h}$ after the last milking. Values are least squares means \pm SEM for 32 ewes studied in experiment 1 in a $6 \times 6$ Latin square design every $3 \mathrm{~d}$ for $18 \mathrm{~d}$. Significant differences between alveolar and cisternal fractions within a time category are indicated by $*(P<0.05)$.

3-d treatment period was lowest $(P<0.01)$ for the 20 and 24-h treatments compared with all other treatments (Table 1).

As milking interval increased, percentage of milk fat decreased $(P<0.01)$, while percentage of milk protein and milk fat yield and protein yield increased $(P<0.01)$ (Table 1). Alveolar percentage of milk fat was higher $(P<0.05)$ than cisternal percentage of milk fat for all intervals except $4 \mathrm{~h}$ (Figure 2A). Alveolar percentage of fat tended to increase from the 8- to the 24-h interval, whereas cisternal percentage of milk fat decreased from the 4- to 20-h interval (Figure 2A). Alveolar milk fat yield increased with increasing milking interval, and was higher $(P<0.05)$ than cisternal milk fat yield at all intervals (Figure 2B). Cisternal milk fat yield increased $(P<0.05)$ through the $4-, 8-$, and 12 -h intervals, was constant during the 16- and 20 -h intervals, and then increased $(P<0.05)$ again for the 24 -h interval (Figure 2B). Milk protein percentage did not differ between cis- ternal and alveolar milk fractions at any of the intervals except at $24 \mathrm{~h}(P<0.05)$ (Figure $2 \mathrm{C})$. Alveolar milk protein yield increased $(P<0.05)$ with increasing milking interval through $20 \mathrm{~h}$, whereas cisternal milk protein yield increased $(P<0.05)$ through the 24 -h interval (Figure 2D).

Overall SCC tended to decrease $(P<0.05)$ from the 4$\mathrm{h}$ through the 16 - $\mathrm{h}$ intervals, and then remained similar through the 24-h interval (Table 1). Alveolar and cisternal SCC were not different during the 4,8 , or 12 -h treatments; however, within the 16-, 20-, and 24-h intervals, cisternal SCC was lower $(P<0.05)$ than alveolar SCC (Figure 3).

\section{Experiment 2}

During the experimental period ( $\mathrm{d} 90$ to the end of lactation), $16 \mathrm{H}$ ewes were machine milked 45 fewer times than $12 \mathrm{H}$ ewes (Table 2). Ewes milked every 12 


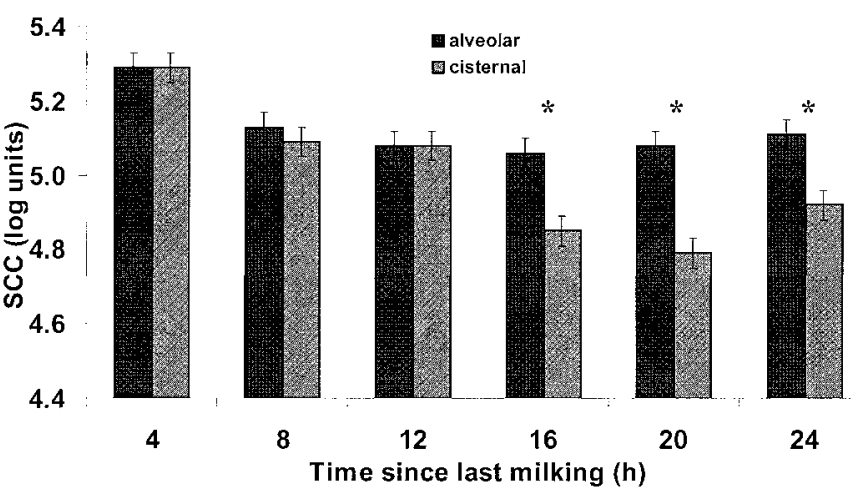

Figure 3. Somatic cell count within alveolar and cisternal milk obtained $4,8,12,16,20$, and $24 \mathrm{~h}$ after the last milking. Values are least squares means \pm SEM for 32 ewes studied in experiment 1 in a $6 \times 6$ Latin square design every $3 \mathrm{~d}$ for $18 \mathrm{~d}$. Significant differences between alveolar and cisternal fractions within a time category are indicated by $*(P<0.05)$.

$\mathrm{h}$ had similar lactation length, milk production, milk fat percentage and yield, milk protein percentage and yield, and SCC than did ewes milked every $16 \mathrm{~h}$ (Table 2). Throughout the experiment $16 \mathrm{H}$, ewes had adjusted 24$\mathrm{h}$ milk yield similar to $12 \mathrm{H}$ ewes (Figure 4); however, morning milk yield was $28 \%$ higher $(P<0.01)$ for $16 \mathrm{H}$ versus $12 \mathrm{H}$ ewes (Table 2 ). The amount of time spent in the milking parlor for each treatment group at an individual milking did not differ; however, total parlor time over the entire experiment was $27 \%$ less (not statis-

Table 2. Least squares means \pm SEM for milk production and composition traits of an individual ewe in the two treatment groups during experiment 2 (d 90 to the end of lactation).

\begin{tabular}{|c|c|c|}
\hline \multirow[b]{2}{*}{ Trait } & \multicolumn{2}{|c|}{ Treatment $^{1}$} \\
\hline & $12 \mathrm{H}$ & $16 \mathrm{H}$ \\
\hline Total number of milkings & 180 & 135 \\
\hline $\begin{array}{l}\text { Lactation length, } \mathrm{d} \\
\text { Morning milk production, } \mathrm{kg} \\
\text { Parlor time, } \min ^{2} \\
\text { Total parlor time, } \mathrm{h}^{3}\end{array}$ & $\begin{aligned} 179.3 & \pm 1.2 \\
0.65 & \pm 0.03^{\mathrm{b}} \\
12.7 & \pm 0.4 \\
38.1 & \end{aligned}$ & $\begin{array}{c}177.5 \pm 1.2 \\
0.83 \pm 0.03^{\mathrm{a}} \\
12.4 \pm 0.4 \\
27.9\end{array}$ \\
\hline $\begin{array}{l}\text { Adj. } 24 \text {-h milk production, } \mathrm{kg} \\
\text { Total milk production, } \mathrm{kg}\end{array}$ & $\begin{aligned} 1.34 & \pm 0.06 \\
119.1 & \pm 5.3\end{aligned}$ & $\begin{aligned} 1.35 & \pm 0.06 \\
118.0 & \pm 5.3\end{aligned}$ \\
\hline $\begin{array}{l}\text { Avg. milk fat, } \% \\
\text { Total milk fat yield, } \mathrm{kg} \\
\text { Avg. milk protein, } \% \\
\text { Total milk protein yield, kg } \\
\text { SCC, } \log _{10} / \mathrm{ml}\end{array}$ & $\begin{aligned} 5.29 & \pm 0.14 \\
6.3 & \pm 0.3 \\
4.64 & \pm 0.07 \\
5.5 & \pm 0.2 \\
4.69 & \pm 0.04\end{aligned}$ & $\begin{aligned} 5.27 & \pm 0.14 \\
6.2 & \pm 0.3 \\
4.73 & \pm 0.07 \\
5.5 & \pm 0.2 \\
4.64 & \pm 0.04\end{aligned}$ \\
\hline
\end{tabular}

${ }^{\mathrm{a}, \mathrm{b}}$ Means within a row with different subscripts differ $(P<0.05)$.

${ }^{1}$ During the experiment, $12 \mathrm{H}$ ewes $(\mathrm{n}=24)$ were milked twice daily $(0600$ and 1800$)$ and $16 \mathrm{H}$ ewes $(\mathrm{n}=24)$ were milked every $16 \mathrm{~h}(0600$, 2200 , and 1400).

${ }^{2}$ Time for parlor entry, machine milking, and parlor exit for a treatment group of 24 ewes during a milking.

${ }^{3}$ Total number of milkings $\times$ parlor time.

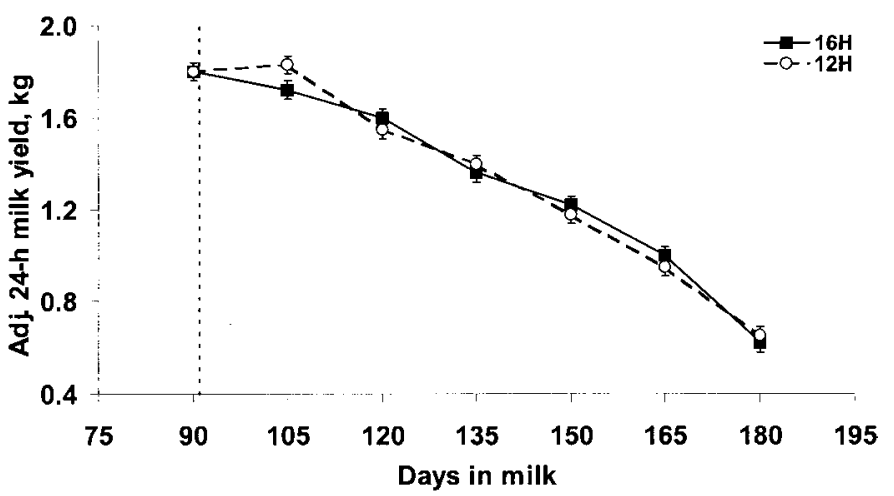

Figure 4. Adjusted 24-h milk yield for the two treatment groups in experiment $2(12 \mathrm{H}=$ ewes milked twice daily at 0600 and $1800 \mathrm{~h}$, $\mathrm{n}=24 ; 16 \mathrm{H}=$ ewes milked every $16 \mathrm{~h}$ at 0600,2200 , and $1400 \mathrm{~h}$, respectively, $\mathrm{n}=24$ ). The dotted vertical line indicates the start of experiment 2 .

tically analyzed) for the $16 \mathrm{H}$ than for $12 \mathrm{H}$ system (Table 2).

\section{DISCUSSION}

\section{Milk Yield}

During the first $12 \mathrm{~h}$ of milk secretion, the East Friesian crossbred dairy ewes in experiment 1 stored the majority of their total milk volume in the alveolar compartment, which is consistent with reports in dairy cattle (Knight et al., 1994a). However, the cisternal compartment began filling as early as $4 \mathrm{~h}$, indicating that there was transfer of milk from the alveoli to the cistern much earlier than in one report in dairy cows (Knight et al., 1994a) but similar to a second report in dairy cows (Stelwagen et al., 1996) and one report in dairy goats (Peaker and Blatchford, 1988). Our result must be interpreted with some caution because the supraphysiologic dose of oxytocin administered at $0 \mathrm{~h}$ could have resulted in continued periodic transfer of milk for up to 30 to 60 min after administration.

Freedom of transfer of milk from the alveoli to the cistern between milkings is an important factor in determining appropriate milking frequencies for dairy cows (Davis et al., 1998), which is consistent with observations of Peaker and Blatchford (1988) who concluded that goats that store relatively more milk in the alveoli between milkings have lower milk secretion rates. In other words, the ability of the cistern to accept dilatation, as a result of milk transfer from the alveoli to the cistern during milk accumulation, might prove to be as important as the animal's genetic potential for milk secretion, as has been suggested for dairy cows (Dewhurst and Knight, 1993; Knight et al., 1994a) and dairy goats (Peaker and Blatchford, 1988). 
When the milking interval exceeded $12 \mathrm{~h}$, the cisternal compartment became more important in accommodating milk storage, which possibly helped reduce alveolar milk stasis, alveolar pressure, and concentration of feedback inhibitors of lactation. Physiologically, increased cisternal storage of milk may be advantageous to milk yield, composition, and quality because a potential feedback inhibitor of lactation (Wilde et al., 1995) and/or certain inhibitory fatty acids (Williamson et al., 1995) can be diverted away from mammary secretory epithelium, and alveolar pressure might be lower, thereby avoiding the deleterious effects on milk synthesis and milk quality from damage to secretory epithelium (Labussière, 1993; Peaker, 1980), and/or impairment to the tight junctions between epithelial cells (Stelwagen et al., 1997). Cows with a greater degree of cisternal filling after $24 \mathrm{~h}$ of milk secretion have significantly lower production loss after once-daily milking, compared with twice-daily milking (Knight and Dewhurst, 1994; Davis et al., 1998).

The cisternal fraction of milk in these experimental East Friesian crossbred ewes did not exceed $60 \%$, which is lower than the maximum of $75 \%$ reported in Sarda ewes (Marnet and McKusick, 2001), most likely due to significant differences between breeds in cisternal storage capacity (Bruckmaier et al., 1997; Capote et al., 1999). All the dairy ewes in the present experiments were studied during their third or fourth lactation (experiments 2 and 1, respectively), which also may have influenced the results because multiparous animals have larger cisternal storage capacity than primiparous animals (Pfeilsticker et al., 1996). In contrast to one report in dairy goats (Peaker and Blatchford, 1988), which stated that alveolar milk volume remained constant after $6 \mathrm{~h}$, alveolar milk yield in experiment 1 continued to increase up to at least $20 \mathrm{~h}$. This discrepancy is probably related to differences between the studies in experimental techniques. The present study used an oxytocin receptor antagonist and oxytocin, whereas the former study used catheter removal and oxytocin.

We observed significant decreases in milk yield in experiment 1 , when the milking interval was equal to or exceeded $16 \mathrm{~h}$ during the first complete 12 -h interval following treatment and during the entire 3 -d treatment period. In fact, following the 24 -h treatment, milk yield remained significantly lower than all other treatments for at least the first three milkings following treatment (data not shown). The longer milking intervals were only used very short term in the present experiment, and the associated reduction in milk yield is more likely due to acute changes in the mammary gland related to tight junction permeability and increased intra-alveolar pressure (Stelwagen, 2001). In the study of Li et al. (1999), continued use of unilateral once-daily milking compared to thrice-daily milking of dairy goats induced increased levels of apoptosis in the once-daily milked udder half as evidenced by less numbers of secretory cells. We therefore hypothesized that a routine milking interval for East Friesian crossbred dairy ewes should not exceed $16 \mathrm{~h}$ (which was subsequently evaluated in experiment 2) to avoid significant losses in overall lactation yield and length; this is slightly shorter than the 18 to $20 \mathrm{~h}$ maximum interval recommended for dairy cattle (Davis and Hughson, 1988).

Our hypothesis was confirmed in experiment 2 because there was no change in milk yield or lactation length for $16 \mathrm{H}$ compared with $12 \mathrm{H}$ ewes, yet a $25 \%$ reduction in the number of milkings was achieved for the $16 \mathrm{H}$ group. The results of experiment 2 demonstrated a clear advantage in milking efficiency for East Friesian crossbred dairy ewes managed with a milking interval of $16 \mathrm{~h}$ during mid- to late lactation (last $90 \mathrm{~d}$ of a 180$\mathrm{d}$ lactation). The amount of milk within the udder at each milking for the $16 \mathrm{H}$ group was greater than for the $12 \mathrm{H}$ group (Table 2); however, this did not influence the amount of time spent in the parlor. This suggests that average milk flow rate for the $16 \mathrm{H}$ group may have been higher than for the $12 \mathrm{H}$ group, which is consistent with one report in dairy cattle that demonstrated a significant positive relationship between milk flow rate and degree of udder filling (Bruckmaier and Hilger, 2001). Most reports concerning the effect of once-daily milking in ewes have shown significant losses of 20 to $60 \%$ in milk production and hypothesize that lactation length would also be reduced (Morag, 1968; Casu and Labussière, 1972; Labussière, 1984; Knight and Gosling, 1994). Apparently, a 16-h milking interval is more appropriate for dairy ewes than a 24-h milking interval, because we observed no detrimental effect on milk yield or lactation persistency. Moreover, the reduction in total labor associated with the $16-\mathrm{h}$ milking interval treatment permits dairy sheep producers more time to devote to other farming practices and/or to other activities off the farm.

Had experiment 2 been conducted during early lactation, it is likely that less frequent milking would have significantly reduced lactation performance of these East Friesian dairy ewes. Less frequent milking during early lactation results in reduced milk yield in dairy cows (Walsh, 1976; Rémond et al., 1999), goats (Wilde and Knight, 1990), and ewes (Knight and Gosling, 1994) and could compromise lactation persistency (Walsh, 1976) because of decreased alveolar diameter (Li et al., 1999) and/or reduced functional udder capacity (Carruthers et al., 1993). Udders of dairy ewes that are managed with a mixed weaning system of suckling and once-daily machine milking in early lactation have large secretory capacity; however, as soon as weaning takes place, milk production drops by 30 to $40 \%$ (McKusick et al., 2001; Labussière and Pétrequin, 1969) due to less frequent 
udder evacuation and severing of the mother-young bond. Therefore, less frequent milking or longer milking intervals for dairy ewes in early lactation may not be a wise management decision. The exact stage of lactation that producers may begin using a 16-h milking interval without significant loss in milk production remains to be determined.

\section{Milk Composition}

Milk fat is considered to be the most variable component in ruminant milk (Barnicoat et al., 1956). This is clearly reflected in experiment 1 , as we observed marked differences among milking intervals in percentage of milk fat (both in total milk and in the cisternal and alveolar fractions), but not necessarily in milk protein percentage. We have shown that although the cistern is capable of storing more than $50 \%$ of the total milk volume, cisternal milk is relatively poor in fat content, which agrees with the observations of Waldmann et al. (1999) in dairy cows and of McKusick et al. (2001) in dairy ewes. Milk fat percentage was high for both cisternal and alveolar fractions at the 4-h milking interval, probably as a result of the recuperation of residual fat that had descended into the cistern during or shortly after the $0 \mathrm{~h}$ milking but was not removed from the udder. Both cisternal and alveolar fat yield increased from the 4- to 12 -h intervals, after which cisternal milk fat yield tended to plateau during the 16 - and 20 -h treatments, while alveolar milk fat yield continued to increase. This indicates that there was transfer of milk fat from the alveoli to the cistern during early udder filling; however, this transfer was no longer taking place during the later intervals, resulting in a accumulation of milk fat in the alveolar compartment. Because milk fat globules in the ewe are large (Muir et al., 1993), active expulsion, either by oxytocin-mediated myoepithelial contraction (see review by Bruckmaier and Blum, 1998) or perhaps by less clearly defined spontaneous contraction mechanisms (Lefcourt and Akers, 1983), is required for milk fat removal from the udder. Our results confirm that up to $70 \%$ of the total fat yield (e.g., at the 20-h treatment) can be contained within the alveoli, which underlines the importance of milk ejection during milk removal (either during suckling or machine milking) for recuperation of milk that is rich in total solids (Labussière, 1969; McKusick et al., 2001).

Milk protein percentage generally was unaffected by milk fraction. This is consistent with hypotheses based on the evolutionary advantage of a mammal to be able to synthesize and provide milk that is consistent in protein concentration regardless of nutrition and/or other potential environmental stressors (Cowie and Tindal, 1971). Milk protein yield, and its distribution between alveolar and cisternal fractions, were highly correlated with milk yield ( $r=0.98$, data not shown) and is explained by the synergistic synthetic pathway for lactose synthesis that involves lactose synthetase and the same intracellular vesicles in the mammary gland (Fitzgerald et al., 1970). Milk protein is found primarily in the form of small casein micelles (Cowie and Tindal, 1971) and presumably passed freely from the alveolar compartment into the cistern between milkings and therefore was less dependent on milk ejection for its removal from the mammary gland than was fat. We did, however, observe a slightly greater milk protein concentration in cisternal compared with alveolar milk at milking intervals of 12 $\mathrm{h}$ and greater (only significant for the 24-h interval).

Cisternal and alveolar SCC were similar for milking intervals through $12 \mathrm{~h}$ in experiment 1 . Thereafter, cisternal SCC was significantly lower than alveolar SCC through the 24-h interval, which is consistent with reports of lower SCC in fore-stripped milk compared with stripped milk in dairy ewes (Gonzalo et al., 1993). Reports in dairy cattle concerning reduced milking frequency have found that SCC increases with decreased milking frequency (Kelly et al., 1998; Hamann and Gyodi, 2000); however, this does not appear to be due to damage of mammary secretory epithelium (Stelwagen and Lacy-Hulbert, 1996). Instead, increased SCC associated with longer milking intervals appear to be due to leaky tight junctions between mammary epithelial cells. However, tight junctions resume their closed state immediately upon milk removal (Stelwagen et al., 1997). Even though we observed that SCC decreased with increasing milking interval, experiment 1 was designed with only one milking interval treatment at the first milking of a 3-d period and would not be entirely comparable to the above reports, which used extended periods of increased milking interval. Nonetheless, in experiment 2 , when the milking interval was extended to 16 $\mathrm{h}$, there were no differences in SCC, or in milk fat or protein percentage compared to ewes milked with a 12$\mathrm{h}$ milking interval at any of the test days, indicating that milk composition and quality are not compromised with use of this longer milking routine during mid- to late lactation. Apparently, the 16-h milking interval in experiment 2 was not sufficiently long enough to cause an increase in the inflammatory response of the udder at this stage in lactation.

One of the novel observations in experiment 1 is the marked increase in milk yield, milk protein yield, and SCC within the cisternal fraction, but not necessarily in the alveolar fraction, for the 24-h interval relative to the 20-h interval. This trend, although less dramatic, was also present for cisternal milk fat yield. Presumably, transfer of milk from the alveoli to the cistern was somehow increased during the last $4 \mathrm{~h}$ of the $24-\mathrm{h}$ milking 
interval. In dairy cattle, the alveolar compartment is full by $16 \mathrm{~h}$ (Davis et al., 1998), and any additional accumulation of milk must be accommodated within the cisternal compartment. The alveoli were presumably full by $20 \mathrm{~h}$ in experiment 1 , which concurs with Davis et al. (1998). However, it is curious that the nonaqueous fraction (e.g., milk fat), which normally remains in the alveoli until the time of milk ejection, also increased in the cisternal fraction between 20 and $24 \mathrm{~h}$. This might be explained by increased pressure and distention within the alveoli and small intramammary ducts causing contraction of these structures (Cross, 1954; Grosvenor, 1965), which could have resulted in expulsion of milk from the upper portions of the udder into the cistern, presumably independent of the oxytocin-mediated milk ejection reflex (Lefcourt and Akers, 1983). Presence of this mechanism might explain some of the individual variation in milk production losses associated with oncedaily milking (Davis and Hughson, 1988). In other words, intramammary compliance or elasticity could play a significant role in determining how often the udder would need to be emptied in order to avoid deleterious effects on milk synthesis due to overaccumulation of milk within the alveoli (Peaker and Blatchford, 1988). This remains an important area of investigation in lactation physiology research.

The increase in protein yield, and to a lesser degree for SCC, between the 20 and 24-h intervals in experiment 1 might also have been due to increased tight junction leakiness (Stelwagen et al., 1997), allowing serum protein to spill over into the milk. Futhermore, high doses of oxytocin also impair mammary tight junctions (Allen, 1990), and because the dose of oxtyocin was somewhat higher than that used by other researchers in small ruminants (Knight et al., 1994b), this may have contributed to influx of serum protein. Because the different milk and nonmilk proteins were not differentiated in experiment 1 , further research is necessary to confirm this hypothesis.

\section{CONCLUSIONS}

Dairy ewes are capable of storing large amounts of milk within the cistern. However, cisternal milk is significantly inferior in milk fat content, compared with alveolar milk, implying that milk ejection during machine milking is obligatory for the removal of milk that is rich in total solids. Milking intervals $\leq 16 \mathrm{~h}$ during mid- and late lactation did not result in significant losses in milk yield, milk composition, or quality, or lactation persistency for East Friesian crossbred dairy ewes. Moreover, significant reductions in labor and time spent in the milking parlor which are associated with longer milking intervals could result in a higher standard of living and enable the farmer to spend more time with other on- or off-farm activities. Finally, the fact that milk transfer from the alveoli to the cistern was increased during the last $4 \mathrm{~h}$ of a 24 -h milking interval merits further investigation of the mechanisms responsible for milk ejection between milkings.

\section{ACKNOWLEDGMENTS}

The authors express their gratitude to the Babcock Institute for International Dairy Research and Development (Madison, WI) who have generously supported the dairy sheep research program at the University of Wisconsin-Madison. The authors wish to thank Sarah Bates, Clayton and Heidi Hiemke, Carissa Hiemke, and Jennifer Lorenz at the Department of Animal Science's Livestock Laboratory and Lori Brekenridge, Ann Stallrecht, Debbie Scalzo, and Richard Schlapper at the Spooner Agricultural Research Station for their committed efforts in the care and maintenance of the animals, and for their excellent help with data collection during the experiments. We thank Ferring Research Institute, Inc., San Diego, CA, for generously providing the oxytocin receptor antagonist Atosiban.

\section{REFERENCES}

Allen, J. C. 1990. Milk synthesis and secretion rates in cows with milk composition changed by oxytocin. J. Dairy Sci. 73:975-984.

Barnicoat, C. R., P. F. Murray, E. M. Roberts, and G. S. Wilson. 1956. Milk secretion studies with New Zealand Romney ewes. Parts VXI. J. Agric. Sci. 48:9-35.

Bruckmaier, R. M., G. Paul, H. Mayer, and D. Schams. 1997. Machine milking of Ost-friesian and Lacaune dairy sheep: Udder anatomy, milk ejection, and milking characteristics. J. Dairy Res. 64:163172.

Bruckmaier, R. M., and J. W. Blum. 1998. Oxytocin release and milk removal in ruminants. J. Dairy Sci. 81:939-949.

Bruckmaier, R. M, and M. Hilger. 2001. Milk ejection in dairy cows at different degrees of udder filling. J. Dairy Res. 68:369-376.

Capote, J., J. L. Lopez, G. Caja, S. Peris, A. Arguello, and N. Darmanin. 1999. The effect of milking once or twice daily throughout lactation on milk production of Canarian dairy goats. Pages 267-273 in Milking and Milk Production of Dairy Sheep and Goats. N. Zervas and F. Barillet, eds. EAAP Publication No. 95. Wageningen Pers, Wageningen, The Netherlands.

Carruthers, V. R., S. R. Davis, A. M. Bryant, H. V. Henderson, C. A. Morris, and P. J. A. Copeman. 1993. Response of Jersey and Friesian cows to once a day milking and prediction of response based on udder characteristics and milk composition. J. Dairy Res. 60:1-11.

Casu, S., and J. Labussière. 1972. Premiers résultants concernant la suppression d'une or plusieurs traits par semaine chez la brebis Sarde. Ann. Zootech. 21:223-232.

Cowie, A. T., and J. S. Tindal. 1971. The Physiology of Lactation. Camelot Press Ltd., London.

Cross, B. A. 1954. Milk ejection resulting from mechanical stimulation of mammary myoepithelium in the rabbit. Nature (Lond.). 173:450-451.

Davis, S. R., and G. A. Hughson. 1988. Measurement of functional udder capacity in lactating Jersey cows. Aust. J. Agric. Res. 39:1163-1168.

Davis, S. R., V. C. Farr, P. J. A. Copeman, V. R. Carruthers, C. H. Knight, and K. Stelwagen. 1998. Partitioning of milk accumulation 
between cisternal and alveolar compartments of the bovine udder: relationship to production loss during once daily milking. J. Dairy Res. 65:1-8.

Davis, S. R., V. C. Farr, and K. Stelwagen. 1999. Regulation of yield loss and milk composition during once-daily milking: a review. Livest. Prod. Sci. 59:77-94.

Dewhurst, R. J., and C. H. Knight. 1993. An investigation of the changes in sites of milk storage in the bovine udder over two lactation cycles. Anim. Prod. 57:379-384.

Fitzgerald, D. K., U. Brodbeck, I. Kiyosawa, R. Mawal, B. Colvin, and K. E. Ebner. 1970. $\alpha$-Lactalbumin and the lactose synthetase reaction. J. Biol. Chem. 245:2103-2108.

Gonzalo, C., J. A. Baro, J. A. Carriedo, and F. San Primitivo. 1993. Use of the Fossomatic method to determine somatic cell counts in sheep milk. J. Dairy Sci. 76:115-119.

Grosvenor, C. E. 1965. Contractions of the lactating rat mammary gland in response to direct mechanical stimulation. Am. J. Physiol. 208:214-218.

Hamann, J., and P. Gyodi. 2000. Somatic cells and electrical conductivity in relation to milking frequency. Milchwissenschaft 55:303-307.

Kelly, A. L., S. Reid, P. Joyce, W. J. Meaney, and J. Foley. 1998. Effect of decreased milking frequency of cows in late lactation on milk somatic cell count, polymorphonuclear leucocyte numbers, composition, and proteolytic activity. J. Dairy Res. 65:365-373.

Knight, C. H., and R. J. Dewhurst. 1994. Once daily milking of dairy cows: relationship between yield loss and cisternal milk storage. J. Dairy Res. 61:441-449.

Knight, C. H., D. Hirst, and R. J. Dewhurst. 1994a. Milk accumulation and distribution in the bovine udder during the interval between milkings. J. Dairy Res. 61:167-177.

Knight, C. H., K. Stelwagen, V. C. Farr, and S. R. Davis. 1994b. Use of an oxytocin analogue to determine cisternal and alveolar milk pool sizes in goats. J. Dairy Sci. 77(Suppl. 1):84. (Abstr.)

Knight, T. W., and L. S. Gosling. 1994. Effects of milking frequency and machine stripping on milk yields of Dorset ewes. Proc. N. Z. Soc. Anim. Prod. 54:261-262.

Labussière, J. 1969. Importance, composition, et significance des différentes fractions de lait obtenues successivement au cours de la traite mécanique des brebis. Ann. Zootech.18:185-196.

Labussière, J., and P. Pétrequin. 1969. Relations entre l'aptitude à la traite des brebis et la perte de production laitière constatée au moment du sevrage. Ann. Zootech. 18:5-15.

Labussière, J., J. F. Combaud, and P. Pétrequin. 1974. Effets de la suppression de la traite du dimanche soir sur les brebis de race Préalpes du Sud. Ann. Zootech. 23:435-444.

Labussière, J. 1984. Etude des aptitudes laitières et de la facilité de traite de quelques races du "Bassin Méditerranéen." Pages 730 792 in Proc. Third Symp. Mach. Milking of Sm. Rum., Valladolid, Spain.

Labussière, J. 1988. Review of the physiological and anatomical factors influencing the milking ability of ewes and the organization of milking. Livest. Prod. Sci. 18:253-274.

Labussière, J. 1993. Physiologie de l'éjection du lait: Conséquences sur la traite. Pages 259-294 in Biologie de la Lactation. INRA, Service de Publications, Versailles, France.

Lefcourt, A. M., and R. M. Akers. 1983. Is oxytocin really necessary for efficient milk removal in dairy cows? J. Dairy Sci. 66:2251-2259.

Li, P., P. S. Rudland, D. G. Fernig, L. M. B. Finch, and C. J. Wilde. 1999. Modulation of mammary development and programmed cell death by the frequency of milk removal in lactating goats. J. Physiol. (Lond.). 519:885-900.

Marnet, P. G., and B. C. McKusick. 2001. Regulation of milk ejection and milkability in small ruminants. Livest. Prod. Sci. 70:125-133.
McKusick, B. C., Y. M. Berger, P. G. Marnet, and D. L. Thomas. 2001. Effect of two weaning systems on milk composition, storage, and ejection in dairy ewes. J. Dairy Sci. 79 (Suppl. 1):234. (Abstr.)

Morag, M. 1968. The effect of varying the daily milking frequency on the milk yield of the ewe and evidence on the nature of the inhibition of milk ejection by half-udder milking. Ann. Zootech. 17:351-369.

Muir, D. D., D. S. Horne, A. J. R. Law, and W. Steele. 1993. Ovine milk. 1. Seasonal changes in composition of milk from a commercial Scottish flock. Milchwissenschaft 48:363-366.

Peaker, M. 1980. The effect of raised intramammary pressure on mammary function in the goat in relation to the cessation of lactation. J. Physiol. (Lond.). 301:415-428.

Peaker, M., and D. R. Blatchford. 1988. Distribution of milk in the goat mammary gland and its relation to the rate and control of milk secretion. J. Dairy Res. 55:41-48.

Pfeilsticker, H. U., R. M. Bruckmaier, and J. W. Blum. 1996. Cisternal milk in the dairy cow during lactation and after preceding teat stimulation. J. Dairy Res. 63:509-515.

Rémond, B., J. B. Coulon, M. Nicloux, and D. Levieux. 1999. Effect of temporary once-daily milking in early lactation on milk production and nutritional status of dairy cows. Ann. Zootech. 48:341-352.

SAS User's Guide: Statistics, Version 8 Edition. 1999. SAS Inst., Inc., Cary, NC.

Stelwagen, K., and S. J. Lacy-Hulbert. 1996. Effect of milking frequency on milk somatic cell count characteristics and mammary secretory cell damage in cows. Am. J. Vet. Res. 57:902-905.

Stelwagen, K., C. H. Knight, V. C. Farr, S. R. Davis, C. G. Prosser, and T. B. McFadden. 1996. Continuous versus single drainage of milk from the bovine mammary gland during a 24 hour period. Exp. Physiol. 81:141-149.

Stelwagen, K., V. C. Farr, H. A. McFadden, C. G. Prosser, and S. R. Davis. 1997. Time course of milk accumulation-induced opening of mammary tight junctions, and blood clearance of milk components. Am. J. Physiol. 273:R379-R386.

Stelwagen, K. 2001. Effect of milking frequency on mammary functioning and shape of the lactation curve. J. Dairy Sci. 84(E. Suppl.):E204-E211.

Thomas, D. L., Y. M. Berger, and B. C. McKusick. 2000. East Friesian germplasm: effects on milk production, lamb growth, and lamb survival. Proc. Am. Soc. Anim. Sci., 1999. Online. Available: http:// www.asas.org/jas/symposia/proceedings/0908.pdf.

Waldmann, A., E. Ropstad, K. Landsverk, K. Sorenson, L. Solverod, and E. Dahl. 1999. Level and distribution of progesterone in bovine milk in relation to storage in the mammary gland. Anim. Reprod. Sci. 56:79-91.

Walsh, J. P. 1976. Bovine milk secretion following the omission of milkings immediately post partum and during mid-lactation. Irish J. Agric. Res. 15:91-106.

Wellnitz, O., R. M. Bruckmaier, C. Albrecht, and J. W. Blum. 1999. Atosiban, an oxytocin receptor blocking agent: Pharmacokinetics and inhibition of milk ejection in dairy cows. J. Dairy Res. 66:1-8.

Wilde, C. J., and C. H. Knight. 1990. Milk yield and mammary function in goats during and after once-daily milking. J. Dairy Res. $57: 441-447$.

Wilde, C. J., C. V. P. Addey, L. M. Boddy, and M. Peaker. 1995. Autocrine regulation of milk secretion by a protein in milk. Biochem. J. 305:51-58.

Williamson, D. H., V. Ilic, and P. Lund. 1995. A role for medium-chain fatty acids in the regulation of lipid synthesis in milk stasis? Pages 239-251 in Intercellular Signaling in the Mammary Gland. C. J. Wilde et al., ed. Plenum Press, New York.

Woolford, M. W., P. J. A. Copeman, A. R. Napper, D. S. M. Phillips, J. H. Williamson, and E. J. Uljee. 1985. Milking intervals: are changes worthwhile? Pages 120-128 in Proc. Ruakura Farmers Conf. 